\title{
Density-dependence in post-recruit Japanese seaperch Lateolabrax japonicus in the Chikugo River, Japan
}

\author{
Jun Shoji ${ }^{1,2, *}$, Masaru Tanaka ${ }^{1}$ \\ ${ }^{1}$ Laboratory of Estuarine Ecology, Field Science Education and Research Center, Kyoto University, Sakyo, \\ Kyoto 606-8502, Japan \\ ${ }^{2}$ Present address: Takehara Fisheries Research Station, Center for Education and Research of Field Science, \\ Hiroshima University, Minato-machi 5-8-1, Takehara, Hiroshima 725-0024, Japan
}

\begin{abstract}
Density-dependence in feeding, growth, and mortality was evident in the post-recruit riverine period (15-20 mm in length) of Japanese seaperch Lateolabrax japonicus located within the estuarine turbidity maximum of the Chikugo River, Japan. Based on otolith microstructure analysis, the weight-specific growth coefficient $\left(G, \mathrm{~d}^{-1}\right)$ and abundance-at-age were estimated for post-recruit Japanese seaperch from 1990 to 2000 . Abundance at recruitment (15 mm, $\left.A_{15}\right)$ and at $20 \mathrm{~mm}\left(A_{20}\right)$, and the mortality coefficient during the post-recruit period $\left(M, \mathrm{~d}^{-1}\right)$ were estimated for each year using the larval production method. The $A_{15}$ varied by a factor of 24 during the $11 \mathrm{yr}$ period, and its variability had a significant effect on $G, M, A_{20}$, and the ratio of $M$ to $G$ as an index of Japanese seaperch relative recruitment potential. $G$ was low, and $M$, ratio of $M$ to $G$, and $A_{20}$ were high when recruitment was successful. A lower coefficient of variation (\%) was observed in $A_{20}(25.0)$ than in $A_{15}$ (33.5) for the $11 \mathrm{yr}$. A significant effect of $A_{15}$ was also found on the prey ingestion of the post-recruit Japanese seaperch. Mean gut fullness (gut content weight per unit body weight) was low when recruitment was successful. Density-dependent regulation through competition for prey resources operates on Japanese seaperch in the post-recruit period corresponding with the migration from Ariake Bay to the Chikugo River, a spatially restricted nursery.
\end{abstract}

KEY WORDS: Fish early life stages · Density-dependence $\cdot$ Survival $\cdot$ Estuarine turbidity maximum • Ariake Bay Resale or republication not permitted without written consent of the publisher

\section{INTRODUCTION}

Estuarine turbidity maxima have been found in coastal plain estuaries throughout the world and are characterized by elevated turbidity and zooplankton biomass and production compared to up-estuary and down-estuary values (Schubel 1968). Estuarine turbidity maxima have been found to serve as predation refuges due to their high turbidity, and as feeding grounds for fish early life stages due to the elevated prey concentration (Jassby et al. 1995, North \& Houde 2003, Islam \& Tanaka 2006). Biotic and abiotic conditions of the estuarine turbidity maximum (ETM) are variable and are affected by changes in freshwater discharge, wind, and tides (Shirota \& Tanaka 1981, Sanford et al. 2001), which can be important determinants for recruitment and survival of estuarine dependent fish by controlling density-independent processes such as feeding conditions and retention of fish and their prey within the ETM region (North \& Houde 2003, Shoji et al. 2005).

Japanese seaperch Lateolabrax japonicus are distributed in coastal waters of eastern Asia and are a commercially and recreationally important resource. The larvae hatch during November to February off Kumamoto, about $40 \mathrm{~km}$ south of the mouth of the 
Chikugo River (see Fig. 1). They are passively transported northward to the Chikugo River estuary by the counter-clockwise residual current that prevails in the upper Ariake Bay and then start to migrate into the river (Ohta 2004). This migration from Ariake Bay to the Chikugo River corresponds with the period of transformation from larvae to juveniles $(15 \mathrm{~mm}$ in standard length, SL; Matsumiya et al. 1981). The larvae and juveniles then inhabit the downriver tip of the ETM region, which is formed about $15 \mathrm{~km}$ up-estuary, with a maximum turbidity of about $4000 \mathrm{mg} \mathrm{l}^{-1}$ (Shirota \& Tanaka 1981). Japanese seaperch dominate the ichthyoplankton community of the river from late winter to early spring (Islam \& Tanaka 2006) and feed almost exclusively on the estuarine copepod Sinocalanus sinensis (Hibino et al. 1999). Biological and physical properties of the river and upper bay, such as turbidity (Shoji et al. 2006b), chlorophyll, and copepod production (Okazaki et al. 2005), fluctuate and are affected by the freshwater discharge of the Chikugo River, which contributes to about $70 \%$ of the total freshwater discharge into the upper Ariake Bay (Inoue 1980). High fluctuations of the recruitment abundance to the ETM (10 times) compared to that of the adult stock biomass $(<2$ times) in Ariake Bay from 1979 to 1984 indicate that density-independent recruitment and density-dependent regulation occur during the post-recruitment of Japanese seaperch (Matsumiya et al. 1985).

Density-dependent regulation has also been considered an important determinant for growth and survival of fish early life stages. Recent field surveys have demonstrated density-dependence in the growth and survival of post-recruitment estuarine fishes (Kimmerer et al. 2000, Martino \& Houde 2004). However, the mechanisms of how density regulates growth and survival of fish early life stages are poorly understood. Recent studies have reported that year-to-year variability in zooplankton density $\left(6-15 \mathrm{l}^{-1}\right.$; Hibino et al. 1999, Shoji et al. 2006b) is lower than that in Japanese seaperch recruitment abundance (by a factor of 40; Shoji et al. 2006a). Since density-dependence becomes evident when competition for space and prey occurs among individuals, the onset of density-dependence in Japanese seaperch may correspond with migration from Ariake Bay into the Chikugo River, a spatially restricted nursery, and the increase in food requirement with growth during the post-recruit period may promote the density-dependent regulation (Watanabe \& Nakamura 1998, Iles \& Beverton 2000).

In this study, we investigated whether Japanese seaperch recruitment to the ETM is controlled by density-independent mortality followed by densitydependent regulation during the post-recruit period in the Chikugo River. Recruitment abundance and post- recruit mortality were estimated using data for an $11 \mathrm{yr}$ period (1990-2000).

\section{MATERIALS AND METHODS}

Biological and physical surveys were conducted around the Chikugo River ETM from 1990 to 2000. Seven sampling stations were set at intervals of about $3-5 \mathrm{~km}$ along the river and off the river mouth in the upper part of Ariake Bay (Fig. 1). The 3 uppermost stations were located within the ETM. Ichthyoplankton sampling was conducted during the spring tide period in late March, which corresponds to the seasonal peak of larval and juvenile Japanese seaperch recruitment into the river (Matsumiya et al. 1981). A conical larva net (1.3 m mouth diameter, $0.33 \mathrm{~mm}$ mesh), which has been used for annual larval and juvenile fish surveys

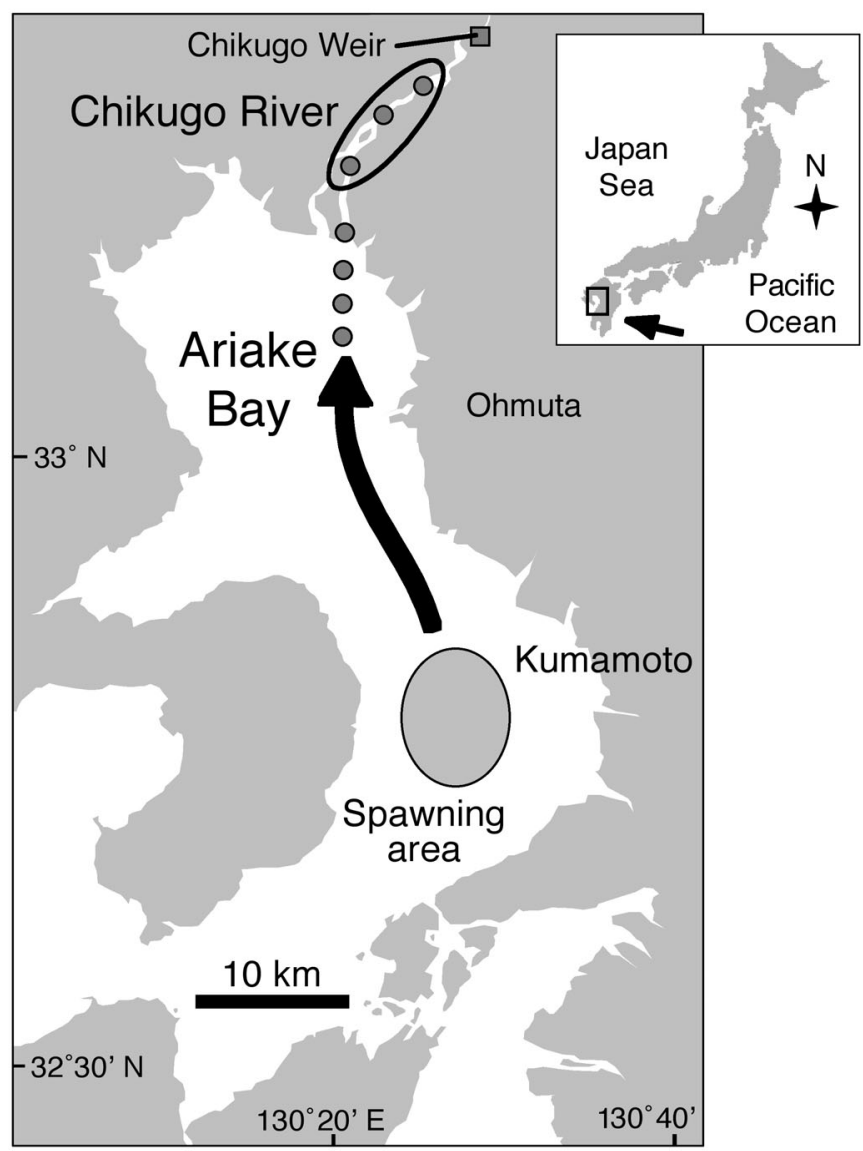

Fig. 1. Sampling stations (O) in the Chikugo River estuary, southwestern Japan, where Japanese seaperch Lateolabrax japonicus larvae and juveniles were collected from 1990 to 2000. The location of the estuarine turbidity maximum (ETM) is indicated by the ellipse downstream of the Chikugo Weir. The arrow shows the transportation pathway of larval Japanese seaperch from their spawning area off Kumamoto to the Chikugo River estuary 
since the 1970s (Matsumiya et al. 1985), was used to collect larval and juvenile Japanese seaperch (> $15 \mathrm{~mm}$ SL) that are abundant in the surface layer in the river and upper bay (Matsumiya et al. 1981). Two $10 \mathrm{~min}$ surface tows were conducted at a ship velocity of 2 knots at each station. Fourteen ichthyoplankton samples were obtained for each year. Japanese seaperch larvae and juveniles were sorted and preserved in $95 \%$ alcohol on the boat. Surface water temperature was measured during each sampling event.

SL of larval and juvenile Japanese seaperch was measured to the nearest $0.1 \mathrm{~mm}$ in the laboratory. The concentration of Japanese seaperch larvae and juveniles in the surface layer $\left(C\right.$, no. $\left.\mathrm{m}^{-3}\right)$ was estimated based on the water volume filtered for each tow (Watanabe et al. 1997). The abundance of larvae and juveniles at each station $\left(A_{\mathrm{s}}\right.$, no. $\left.100 \mathrm{~m}^{-2}\right)$ was calculated according to the ratio of fish concentration in the upper $(<3 \mathrm{~m}$ in depth):bottom layers (1:0.24; Matsumiya et al. 1981) as follows:

$$
A_{\mathrm{s}}=\left[C \times 3+C_{s} \times 0.24 \times(S-3)\right] \times 100
$$

where $S$ is the depth at each station (m). The average depth of the 7 stations was $7.1 \mathrm{~m}$ (range: 5.5-9.7 m). Although Japanese seaperch $<25 \mathrm{~mm}$ SL have been reported to be effectively collected with the larva net in the Chikugo River estuary (Matsumiya et al. 1985), we excluded data on fish $>20 \mathrm{~mm}$ (3.8\% in number of total fish collected) from the analyses in order to estimate the fish abundance more accurately.

Fifty fish (ranging from $15-20 \mathrm{~mm}$ ), randomly selected from the samples for each year, were processed for otolith and gut content analyses. The right sagittal otolith was removed under a dissecting microscope. The majority of these fish (>90\% in each year) were sampled at the river stations located within the ETM (Ohta 2004). Otolith daily increments were counted using a video monitor and an otolith reading system (ARP/W, Ratoc System Engineering). Age of Japanese seaperch larvae and juveniles was estimated by adding 4 to the increment counts, as the first daily increment is deposited at Day 4 (the first feeding) in this species (Ohta 2004). Ages of the larvae and juveniles that were not estimated directly by the otolithbased technique were estimated from an age-length regression constructed for each year (see 'Results'). Instantaneous daily mortality rates of Japanese seaperch during the riverine $(>15 \mathrm{~mm})$ period were calculated from the exponential model of decline:

$$
A_{t}=A_{15} \times \exp (-M \times t)
$$

where $A_{t}$ is the estimated abundance (no. $100 \mathrm{~m}^{-2}$ ) at age $t$ (days after reaching $15 \mathrm{~mm} \mathrm{SL}$ ), $A_{15}$ is the estimated abundance at $15 \mathrm{~mm}$ (no. $100 \mathrm{~m}^{-2}$ ), and $M$ is the instantaneous daily mortality coefficient between 15 and $20 \mathrm{~mm}$. The $A_{15}$ was used as a recruitment index of Japanese seaperch for each year.

Larvae, juveniles, and gut contents were dried for $48 \mathrm{~h}$ at $60^{\circ} \mathrm{C}$ and weighed on a microbalance scale to the nearest $0.0001 \mathrm{mg}$. A weight-specific growth coefficient during the riverine period $(15-20 \mathrm{~mm}: G)$ was estimated for each year as:

$$
W_{t}=W_{15} \times \exp (G \times t)
$$

where $W_{t}$ is the weight $(\mathrm{mg})$ at time $t$ (days after reaching $15 \mathrm{~mm}), W_{15}$ is the weight at $15 \mathrm{~mm}$, and $G$ is the weight-specific growth coefficient. Relative recruitment potential of Japanese seaperch was assessed for each year by examining the ratio of $M$ to $G$, which is sometimes referred to as the 'physiological mortality rate' and can serve as an index of cohort dynamics and productivity that integrates mortality and growth processes (Houde 1996). Gut fullness $(F)$ for each fish was calculated as: $F=P / B$ where $P$ is prey mass and $B$ is fish body mass in mg. Correlations between Japanese seaperch abundance at $15 \mathrm{~mm}\left(A_{15}\right)$ and the indices of feeding $(F)$, growth $(G)$, and mortality $(M)$ were detected.

Daily mean freshwater discharge data (Ministry of Land, Infrastructure, and Transport 1992-2002) for the Chikugo Weir, Fukuoka Prefecture $(25.9 \mathrm{~km}$ upriver from the river mouth, Fig. 1), was used as a measure of the freshwater discharge through the Chikugo River. Similar to the approach used in previous studies where significant effects of river flow on fish recruitment were found (Crecco \& Savoy 1984, North \& Houde 2003), Pearson correlation coefficients were calculated between the monthly mean freshwater discharge and $A_{15}$ to explore possible relationships between river flow and Japanese seaperch recruitment abundance.

\section{RESULTS}

Mean absolute growth rate $\left(\mathrm{mm} \mathrm{d}^{-1}\right)$ of Japanese seaperch between 15 and $20 \mathrm{~mm}$ SL ranged from 0.0585 to 0.1224 and was 0.0746 when all data for the $11 \mathrm{yr}(\mathrm{n}=550)$ were pooled (Table 1$)$. The weightspecific growth coefficient $\left(G, \mathrm{~d}^{-1}\right)$ ranged from 0.0205 to 0.0286 , with an overall mean of 0.0231 .

Exponential models best fit the decline in the abundance of Japanese seaperch larvae and juveniles between 15 and $20 \mathrm{~mm}$ (Fig. 2). The recruitment index (abundance at $15 \mathrm{~mm}, A_{15}$ ) fluctuated by a factor of 24 over the $11 \mathrm{yr}$, with the highest value in 1999 (1.884) and the lowest in $1991(0.078)$. Mean $A_{15}( \pm \mathrm{SD})$ and coefficient of variation $(\mathrm{CV}, \%)$ for the $11 \mathrm{yr}$ were 0.583 $( \pm 0.647)$ and 33.5 , respectively. There was no significant correlation between the $A_{15}$ and mean monthly freshwater discharge for any month $(p>0.05)$ except 
Table 1. Lateolabrax japonicus. Regressions for body length $\left(L_{,} \mathrm{mm}\right)$-age $\left(D_{h_{1}}\right.$ days after hatching) and for dry body weight $(W, \mathrm{mg})$-days after recruitment $\left(D_{r}\right)$ for larvae and juveniles collected in the Chikugo River estuary from 1990 to 2000. Fifty fish were analyzed for each year. All p-values for each regression were $<0.0001$

\begin{tabular}{|lcccc|}
\hline Year & $L-D_{h}$ regression & $\mathrm{r}^{2}$ & $W$ - $D_{r}$ regression & $\mathrm{r}^{2}$ \\
\hline 1990 & $L=0.0942 D_{h}+10.155$ & 0.704 & $W=3.061 \mathrm{e}^{0.0216 D_{r}}$ & 0.795 \\
1991 & $L=0.0664 D_{h}+11.249$ & 0.758 & $W=2.770 \mathrm{e}^{0.0286 D_{r}}$ & 0.920 \\
1992 & $L=0.0908 D_{h}+9.3673$ & 0.683 & $W=4.248 \mathrm{e}^{0.0267 D_{r}}$ & 0.916 \\
1993 & $L=0.0794 D_{h}+10.425$ & 0.477 & $W=3.870 \mathrm{e}^{0.0234 D_{r}}$ & 0.894 \\
1994 & $L=0.1021 D_{h}+9.7457$ & 0.705 & $W=3.124 \mathrm{e}^{0.0239 D_{r}}$ & 0.938 \\
1995 & $L=0.1034 D_{h}+7.8825$ & 0.624 & $W=4.973 \mathrm{e}^{0.0207 D_{r}}$ & 0.791 \\
1996 & $L=0.0585 D_{h}+11.201$ & 0.657 & $W=4.735 \mathrm{e}^{0.0205 D_{r}}$ & 0.739 \\
1997 & $L=0.0875 D_{h}+8.9170$ & 0.542 & $W=5.411 \mathrm{e}^{0.0212 D_{r}}$ & 0.885 \\
1998 & $L=0.1173 D_{h}+8.7403$ & 0.759 & $W=3.688 \mathrm{e}^{0.0246 D_{r}}$ & 0.794 \\
1999 & $L=0.1062 D_{h}+8.5540$ & 0.674 & $W=4.759 \mathrm{e}^{0.0205 D_{r}}$ & 0.918 \\
2000 & $L=0.1224 D_{h}+7.5116$ & 0.743 & $W=4.054 \mathrm{e}^{0.0221 D_{r}}$ & 0.838 \\
Overall & $L=0.0746 D_{h}+10.754$ & 0.598 & $W=4.003 \mathrm{e}^{0.0231 D_{r}}$ & 0.801 \\
\hline
\end{tabular}

March. A power model best described the relationship between $A_{15}$ and mean daily freshwater discharge in March ( $p=0.010$, Fig. 3). The March freshwater discharge fluctuated between $42.6 \mathrm{~m}^{3} \mathrm{~s}^{-1}$ (1999) and $202.1 \mathrm{~m}^{3} \mathrm{~s}^{-1}$ (1992). $A_{15}$ was high and variable in years of low March freshwater discharge $\left(<100 \mathrm{~m}^{3} \mathrm{~s}^{-1}\right)$ and was low in years of high March river flow (>100 $\mathrm{m}^{3} \mathrm{~s}^{-1}$ ).

The mortality coefficient $(M)$ ranged between 0.0174 (1992) and 0.0708 (1999, Fig. 2). Mean ( \pm SD) $M$ and CV for the $11 \mathrm{yr}$ were $0.041( \pm 0.017)$ and 12.2, respectively. Successful recruitment corresponded with low $G$, high $M$, and high $M: G$ ratio. The plot of $G$, $M$ and $M: G$ ratio to $A_{15}$ was best described by a logarithmic formula (Fig. 4a,b,c). Variability in the abundance of Japanese seaperch at $20 \mathrm{~mm}$ $\left(A_{20}\right)$ was lower than that in $A_{15}$. The $A_{20}$ fluctuated by 9.4 times over the $11 \mathrm{yr}$, ranging between 0.015 (1990) and 0.1423 (2000). Mean $( \pm$ SD) and $\mathrm{CV}$ of $A_{20}$ were $0.0485( \pm 0.0402)$ and 25.0 , respectively. The $A_{20}$ increased asymptotically with the increase in $A_{15}$, and the plot of $A_{20}$ to $A_{15}$ was expressed by a logarithmic formula (Fig. 4d). $A_{15}$ also had a significant effect on the prey ingestion rate of Japanese seaperch. The mean value of gut fullness $(F)$ was higher and more variable in years of low $A_{15}$ and was low in years of high $A_{15}$. The

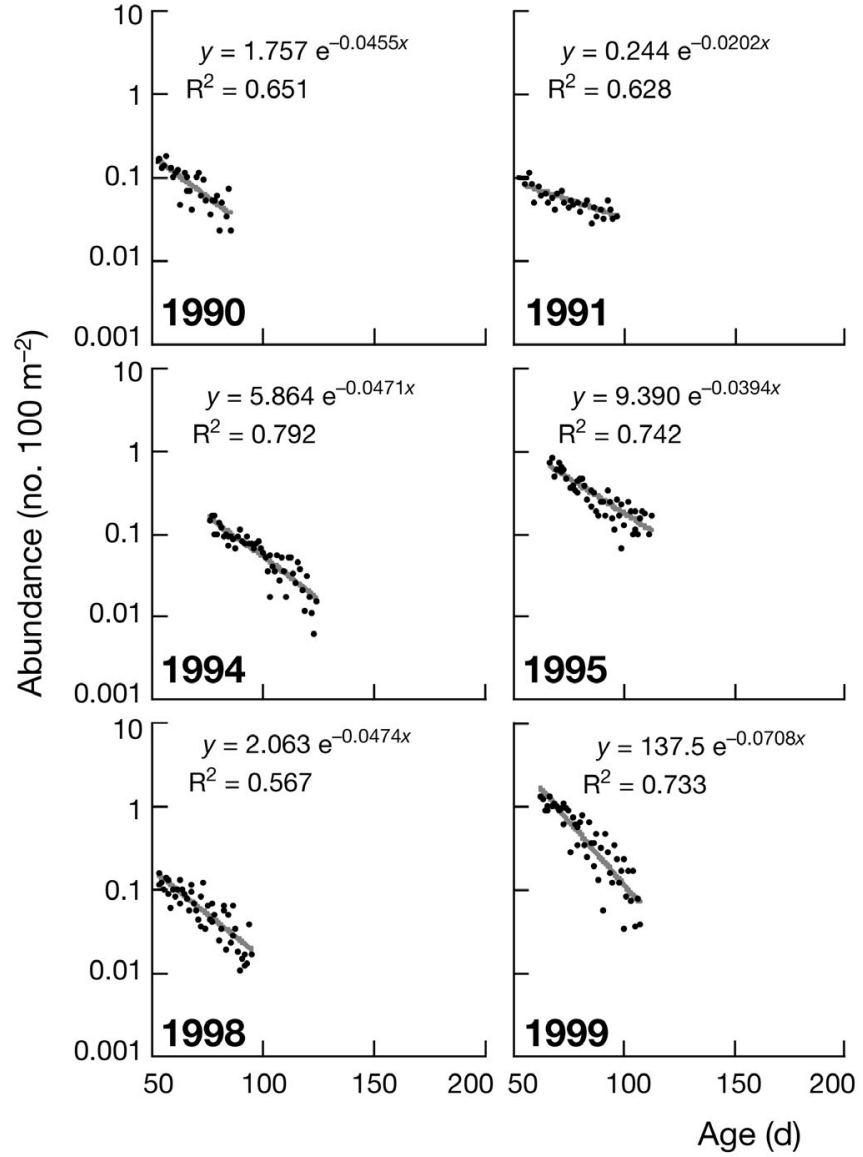

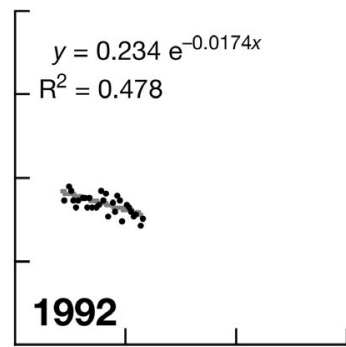

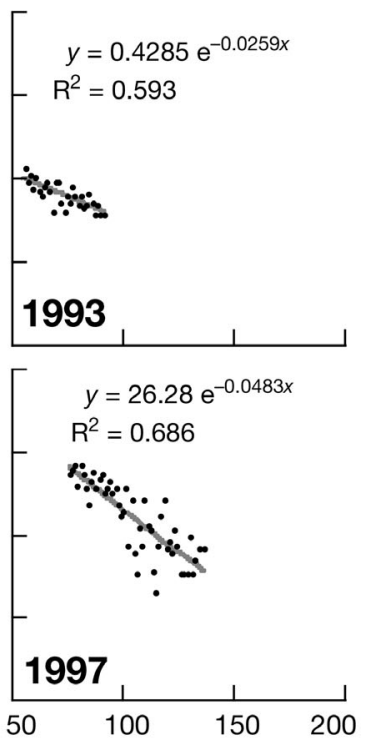

Fig. 2. Lateolabrax japonicus. Abundance at ages of larvae and juveniles from 1990 to 2000. An exponential model was fitted to the decline in the abundance to estimate the mortality coefficient during the post-recruitment period (from 15 to $20 \mathrm{~mm}$ ) for each year. Relationships between the abundance and age are indicated. All p-values were $<0.0001$ 


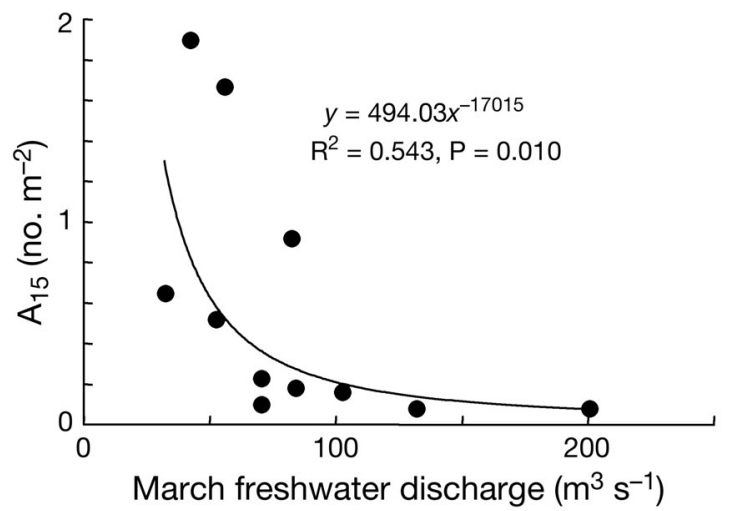

Fig. 3. Lateolabrax japonicus. Plot of recruitment indices (abundance at $15 \mathrm{~mm}$ standard length, SL: $A_{15}$, no. $\mathrm{m}^{-2}$ ) to the mean daily freshwater discharge from the Chikugo River in March from 1990 to 2000 . A power model fitted to the relationship is indicated

mean $F$ was inversely correlated with $A_{15}$ and was best described by an exponential regression (Fig. 4e).

\section{DISCUSSION}

\section{Density-independent recruitment: effect of river flow}

The significant correlation between Japanese seaperch recruitment and March freshwater discharge indicates that a density-independent mechanism controls egg or larval survival during the pre-recruitment period, as reported in a variety of estuarine fish species and ecosystems (Crecco \& Savoy 1984, North \& Houde 2003). Temperature and feeding condition seemed to be more favorable for pre-recruit estuarine stages of Japanese seaperch in years of high freshwater discharge through the Chikugo River. Temperature of the upper Ariake Bay increases with the increase in freshwater discharge during winter to early spring (Shoji et al. 2006a). Production of prey copepods in the upper Ariake Bay also increases when the freshwater discharge increases (Okazaki et al. 2005). Reflecting the variability in these environmental conditions, the growth rate during the estuarine stage $(<15 \mathrm{~mm})$ of Japanese seaperch larvae back-calculated from the otolith microstructures was high in years of high freshwater discharge. However, high recruitment did not correspond with high larval growth rate; the larval growth rate was high but recruitment was low in 1990 and 1998 (Shoji et al. 2006a). Generally, a short larval period due to fast growth is expected to increase survival during the larval stage, when stage-specific cumulative mortality is the highest through life (Houde 1987). However, these observations show that the Japanese seaperch recruitment variability was not well explained by temperature, feeding condition, and/or growth during the larval stage.

We suggest that more direct processes dependent on the physical conditions caused by the high freshwater discharge may regulate survival during the estuarine stage of Japanese seaperch. Physical and biological surveys at 4-6 d intervals in spring of 2005, a year of
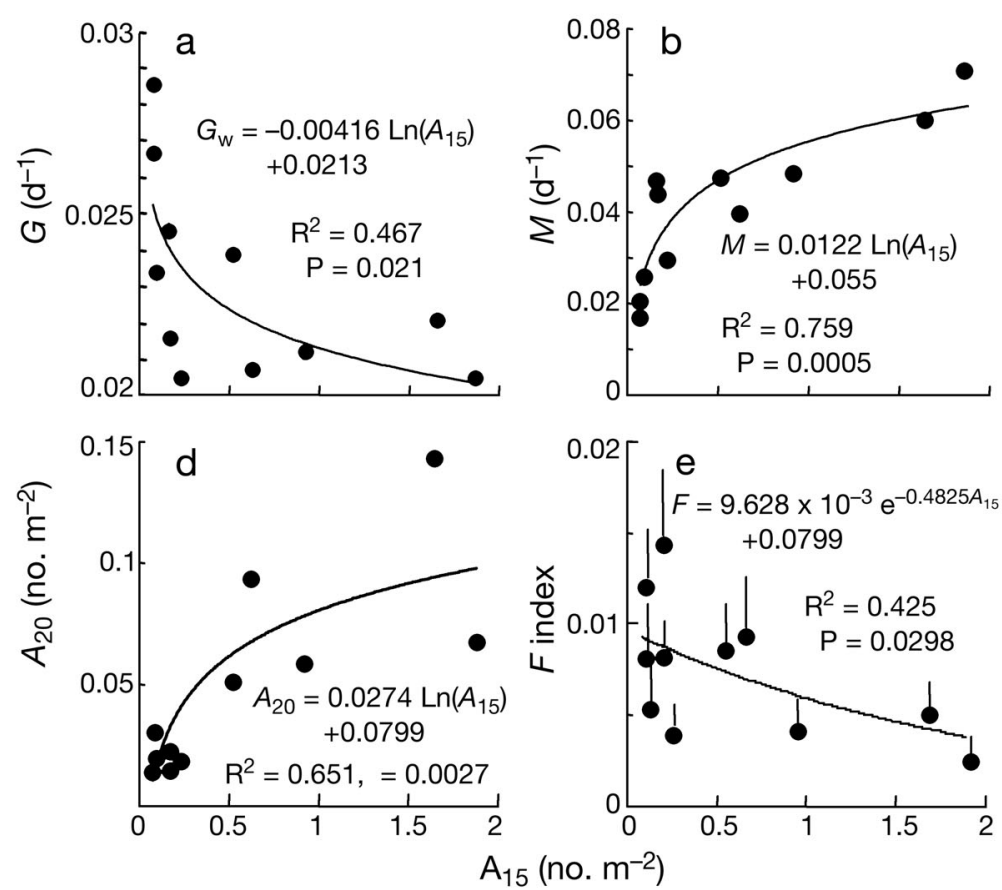

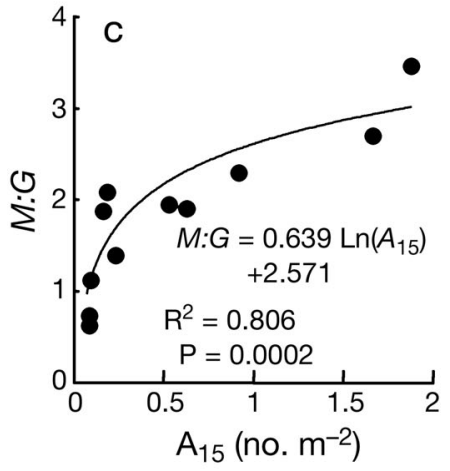

Fig. 4. Lateolabrax japonicus. Plots of (a) weight-specific growth coefficient $\left(G, \mathrm{~d}^{-1}\right)$, (b) instantaneous mortality coefficient $(M$, $\left.\mathrm{d}^{-1}\right)$, (c) the ratio of $G$ to $M_{1}(\mathrm{~d})$ abundance at $20 \mathrm{~mm}$ standard length, SL $\left(A_{20}\right.$, no. $\left.\mathrm{m}^{-2}\right)$, and (e) gut fullness index $(F)$ to recruitment index (abundance at $15 \mathrm{~mm}$ SL: $A_{15}$, no. $\mathrm{m}^{-2}$ ) from 1990 to 2000 (each point represents a specific year). The logarithmic or exponential formula that best describes the relationship is shown in each panel. Panel (e) vertical bars: +SD 
extremely high freshwater discharge during late March in the Chikugo River (Shoji et al. 2006b), demonstrated that the peak abundance of Japanese seaperch moved upriver by $26.8 \mathrm{~km}$ during $6 \mathrm{~d}$ soon after daily freshwater discharge dropped by half in late March, suggesting that high freshwater discharge had prevented immigration of Japanese seaperch into the river. High freshwater discharge transforms the Chikugo River from a well-mixed estuary to a saltwedge estuary (Shirota \& Tanaka 1981, Shoji et al. 2006b). Even if Japanese seaperch successfully migrated into the river, they would be highly vulnerable to downstream transportation under high flow conditions since they are distributed mainly in the surface layers of the Chikugo River (Matsumiya et al. 1981).

Japanese seaperch seem to be subject to less vulnerability to starvation and predation during the prerecruit estuarine period in the upper Ariake Bay. Pelagic pre-recruit Japanese seaperch larvae are distributed in the surface layer, where they are provided with ample prey because of the high concentration of zooplankton in the surface layer of upper Ariake Bay (Okazaki et al. 2005). Potential piscivorous fish predators of Japanese seaperch larvae and juveniles in the ETM region are not very abundant from winter through spring (Yamazaki 2002, K. Suzuki unpubl. data). These ecological conditions of high prey availability and low predator abundance may produce the discharge-related regulation as one of the most important determinants for recruitment of Japanese seaperch in the Chikugo River.

\section{Onset of density-dependence after recruitment}

A shift in habitat from a broad area to a more spatially restricted nursery may correspond with the timing when density-dependent regulation starts to operate in estuarine dependent fish. In the upper Chesapeake Bay, Maryland (USA), growth and survival during the post-recruitment period of striped bass Morone saxatilis is inversely correlated with their recruitment abundance, indicating that densitydependent regulation starts after the immigration to shallow nursery areas, when juveniles begin to feed on benthic prey resources (Martino \& Houde 2004), while survival during the pre-recruit period is well explained by a density-independent process, i.e. the variability in spring freshwater discharge (North \& Houde 2003). Density-dependent growth during the period following migration from oceanic waters to coastal areas was also inferred for larval Japanese sardine Sardinops melanosticta by a comparison of growth between 2 yr of contrasting recruitment abundance (Watanabe \& Nakamura 1998). The significant effect of Japanese seaperch recruitment abundance on post-recruit feeding, growth, and mortality indicates that densitydependent controls operated after the recruitment to a spatially restricted riverine nursery, although these rates and their variability during the pre-recruit period are unknown.

Variability in larval and juvenile fish abundance can control their ingestion and growth by affecting prey abundance (Kiørboe et al. 1988). Jenkins et al. (1991) reported a significant effect of larval southern bluefin tuna Thunnus maccoyii abundance on their growth in the East Indian Ocean and suggested that competition for food among fish larvae and subsequent densitydependent growth might be likely in such oligotrophic waters, and that the mechanisms which produce density-dependence might be quite different from those in riverine environments. However, recent field surveys have reported density-dependence in growth (Martino \& Houde 2004) and survival (Kimmerer et al. 2000, Martino \& Houde 2004) of juvenile striped bass in estuarine ecosystems. In the present study, similar to these previous studies, density-dependence in feeding, growth, and mortality were evident during the postrecruitment stage in Japanese seaperch.

Why does density-dependence occur in highly productive estuarine ecosystems? We suggest that high variability in Japanese seaperch recruitment (by a factor of 24 during the $11 \mathrm{yr}$ period) is a factor that made the density-dependence evident during the riverine period. In the Chikugo River, Sinocalanus sinensis is the almost exclusive prey species for Japanese seaperch, comprising approximately $99.9 \%$ (by number) of mesoand macro-zooplankton in March (Hibino et al. 1999). Daily consumption by Japanese seaperch larvae and early juveniles is $43.5-60.0 \%$ of their body weight (Nanbu 1977). Their prey requirements would exponentially increase due to the increase in their body weight during the riverine stage (Table 1). Since Japanese seaperch are the most dominant consumers within the ichthyoplankton community around the ETM in the Chikugo River in March (Islam \& Tanaka 2006), density-dependence is most likely caused by intra-specific competition for $S$. sinensis.

It is likely that the amount of mortality from predation and its variability during the post-recruit period is small compared to that generated from starvation itself and starvation-related mortalities in the Chikugo River. At the moment, we have no direct evidence of larval and juvenile Japanese seaperch predation by piscivorous fish in the field, and no possible predators have been found in the river during winter through spring (K. Suzuki unpubl. data). In addition, the highly turbid condition in the Chikugo River estuary would work as predation refuge for post-recruit Japanese seaperch. Recent successive physical surveys around the ETM have shown that water 
with turbidity >200 nephelometer turbidity units (NTU) prevailed over an area extending up to $10 \mathrm{~km}$ from the river mouth during the spring tide period from winter to spring in 2005 (Shoji et al. 2006b). Predation would be minimal in the Chikugo River, since reaction distance to prey and consumption rate by visual fish predators decrease under conditions with turbidity >200 NTU (Vinyard \& O'Brien 1976, Miner \& Stein 1993). On the other hand, in years of successful recruitment, decreases in nutritional intake due to densitydependence can increase the possibility of downstream dispersion (Sirois \& Dodson 2000) of Japanese seaperch. Once they are transported down to the upper bay area, vulnerability to predation would increase since potential predators such as piscivorous fish and jellyfish are more abundant there (Shoji et al. 2006b).

\section{Regulation of population biomass}

The year-to-year fluctuation in standing biomass at each life stage of Japanese seaperch seems to decrease at older life stages. Fish abundance at $15 \mathrm{~mm}, 20 \mathrm{~mm}$, and adult stage fluctuated by $24,9.4$, and $<2$ times over the $11 \mathrm{yr}$ period. It is likely that a compensatory effect works on the regulation of Japanese seaperch biomass. In other words, a larval cohort with successful recruitment in a year of low spring freshwater discharge encounters high density-dependent mortality during the post-recruitment period. On the other hand, a larval cohort experiencing high mortality in a year of high spring freshwater discharge would subsequently experience low mortality during the post-recruitment period in the river.

In conclusion, a density-independent, dischargerelated control prevails as the primary determinant for recruitment of larval and juvenile Japanese seaperch, affecting the probability of migration into the Chikugo River. Density-dependent feeding, growth, and mortality were evident during the post-recruit estuarine stage. Utilization of the riverine area, a spatiallyrestricted nursery, seems to contribute to the stabilization of the biomass of the Japanese seaperch population in Ariake Bay through density-dependent regulation.

Acknowledgements. We thank E. D. Houde and E. J. Martino, Chesapeake Biological Laboratory, University of Maryland, for reading an earlier version of this manuscript. Y. Yamashita and R. Masuda, Maizuru Fisheries Research Station, Kyoto University, and T. Ohta, Tottori Prefecture Fisheries Experimental Station, provided valuable comments. T. Sakemi, K. Sakemi, S. Koga, T. Ueda and the former students and staff of our laboratory supported field samplings. This study was supported by in part by Grants-in-Aid from the Ministry of Education, Culture, Sports, Science, and Technology (MEXT), and the Nippon Life Insurance Foundation.

\section{LITERATURE CITED}

Crecco VA, Savoy TF (1984) Effects of fluctuations in hydrographic conditions on year-class strength of American shad (Alosa sapidissima) in the Connecticut River. Can J Fish Aquat Sci 41:1216-1223

Hibino M, Ueda H, Tanaka M (1999) Feeding habits of Japanese temperate bass and copepod community in the Chikugo River Estuary, Ariake Sea, Japan. Nippon Suisan Gakkaishi 65:1062-1068 (in Japanese with English abstract)

Houde ED (1987) Fish early life dynamics and recruitment variability. Am Fish Soc Symp 2:17-29

Houde, ED (1996) Evaluating stage-specific survival during the early life of fish. In: Watanabe Y, Yamashita Y, Oozeki $Y$ (eds) Survival strategies in early life stages of marine resources. A. A. Balkema, Rotterdam, p 51-66

Inoue N (1980) Physics of Ariake Bay. Monthly Kaiyo 12: 116-126 (in Japanese)

Iles TC, Beverton RJ (2000) The concentration hypothesis: the statistical evidence. ICES J Mar Sci 57:216-227

Islam MI, Tanaka M (2006) Spatial variability in nursery functions along a temperate estuarine gradient: role of detrital versus algal trophic pathways. Can J Fish Aquat Sci 63: $1848-1864$

Jassby AD, Kimmerer WJ, Monismith SG, Armor C, Cloern JE, Powell TM, Schubel JR, Vendlinski TJ (1995) Isohaline position as a habitat indicator for estuarine populations. Ecol Appl 5:272-289

Jenkins GP, Young JW, Davis TLO (1991). Density dependence of larval growth of a marine fish, the southern bluefin tuna, Thunnus maccoyii. Can J Fish Aquat Sci 48: $1358-1363$

Kimmerer WJ, Cowan JH, Miller LW, Rose KA (2000) Analysis of an estuarine striped bass (Morone saxatilis) population: influence of density-dependent mortality between metamorphosis and recruitment. Can J Fish Aquat Sci 57: 478-486

Kiørboe T, Munk P, Richardson K, Christensen V, Paulsen H (1988) Plankton dynamics and larval herring growth, drift and survival in a frontal area. Mar Ecol Prog Ser 44:205-219

Martino EJ, Houde ED (2004) Environmental controls and density dependent constraints in the recruitment process of striped bass Morone saxatilis in the estuarine transition zone of Chesapeake Bay. ICES CM 2004/J05:1-24

Matsumiya Y, Kaminosono S, Tanaka M, Shirota A, Yamashita T (1981) Studies on the juvenile Japanese sea bass in the Chikugo estuary of Ariake Bay-1. Bull Jap Soc Fish Oceanogr 38:6-13

Matsumiya Y, Masumoto H, Tanaka M (1985) Ecology of ascending larval and early juvenile Japanese sea bass in the Chikugo River estuary. Nippon Suisan Gakkaishi 51: 1955-1961 (in Japanese with English abstract)

Miner JG, Stein RA (1993) Interactive influence of turbidity and light on larval bluegill (Lepomis macrochirus) foraging. Can J Fish Aquat Sci 50:781-788

Ministry of Land, Infrastructure, and Transport (1992-2002) Chronological table of river flow. Japan River Association, Tokyo

Nanbu T (1977) Studies on Japanese seaperch seed production. IX. Feeding and gut evacuation rate of larval and juvenile Japanese seaperch. Bull Kumamoto Pref Fish Exp Lab 1975:224-229 (in Japanese)

North EW, Houde ED (2003) Linking ETM physics, zooplankton prey, and fish early-life histories to striped bass Morone saxatilis and white perch $M$. americana recruitment. Mar Ecol Prog Ser 260:219-236 
Ohta T (2004) Ecological studies on the river ascending migration of Japanese sea bass Lateolabrax japonicus in Ariake Bay, on the basis of otolith information. PhD dissertation, Kyoto University (in Japanese with English abstract)

Okazaki Y, Hosoe Y, Nonaka Y, Nakata H (2005) Spatial and temporal distribution of copepod nauplii in Ariake Bay. Bull Jap Soc Fish Oceanogr 69:10-17

Sanford LP, Suttles SE, Halka JP (2001) Reconsidering the physics of the Chesapeake Bay estuarine turbidity maximum. Estuaries 24:655-669

Shirota A, Tanaka K (1981) Studies on the suspended matter in the Ariake Bay-I. Transportation of the clay floc-suspension from the Chikugo River to the estuary. Bull Seikai Reg Fish Res Lab 56:27-38 (in Japanese with English abstract)

Schubel JR (1968) Turbidity maximum of the northern Chesapeake Bay. Science 161:1013-1015

Shoji J, North EW, Houde ED (2005) The feeding ecology of white perch Morone americana (Pisces) larvae in the Chesapeake Bay estuarine turbidity maximum: the influence of physical conditions and prey concentrations. J Fish Biol 66:1328-1341

Shoji J, Ohta T, Tanaka M (2006a) Effects of river flow on larval growth and survival of Japanese seaperch Lateolabrax japonicus (Pices) in the Chikugo River estuary, upper Ariake Bay. J Fish Biol 69:1662-1674

Editorial responsibility: Otto Kinne (Editor-in-Chief), Oldendorf/Luhe, Germany
Shoji J, Suzuki KW, Tanaka M (2006b) Effect of tide and river flow on physical and biological properties in the estuarine turbidity maximum of the Chikugo River estuary during spring in 2005: evaluation as a nursery for the estuarinedependent fish, Japanese seaperch Lateolabrax japonicus. Bull Jap Soc Fish Oceanogr 70:31-38

Sirois P, Dodson JJ (2000) Critical periods and growthdependent survival of larvae of an estuarine fish, the rainbow smelt Osmerus mordax. Mar Ecol Prog Ser 203: 233-245

Vinyard GL, O'Brien WJ (1976) Effects of light and turbidity on the reactive distance of bluegill (Lepomis macrochirus). J Res Board Can 33:2845-2849

Watanabe Y, Nakamura M (1998) Growth trajectory of the larval Japanese sardine, Sardinops melanostictus, transported into the Pacific coastal waters off central Japan. Fish Bull 96:900-907

Watanabe Y, Oozeki Y, Kitagawa D (1997) Larval parameters determining preschooling juvenile production of Pacific saury (Cololabis saira) in the northwestern Pacific. Can J Fish Aquat Sci 54:1067-1076

Yamazaki Y (2002) Effectiveness of hatchery-raised juveniles released to a brackish lake Hinuma. In: Tanaka $\mathrm{M}$, Kinoshita I (eds) Temperate bass and biodiversity: new perspective for fisheries biology. Koseisha Koseikaku, Tokyo, p 32-43

Submitted: March 1, 2006; Accepted: August 30, 2006 Proofs received from author(s): March 20, 2007 